\title{
Stand against Poverty: An Interview with Thomas Pogge
}

\author{
Melina Duarte ${ }^{1}$ \\ Department of Philosophy, UiT The Arctic University of Norway, \\ melina.duarte@uit.no
}

DOI: http://dx.doi.org/10.5324/eip.v10i2.1931

(cc) BY

This is an open access article distributed under the terms of the Creative Commons Attribution 4.0 International License, which permits unrestricted use, distribution, and reproduction in any medium, provided the original author and source are credited.

\section{Introduction}

Thomas Pogge is Leitner Professor of Philosophy and International Affairs and Director of the Global Justice Program at Yale University, Professor of Political Philosophy at the Centre for Professional Ethics of the University of Central Lancashire and Research Director at the Centre for the Study of Mind in Nature at the University of Oslo. His life and career have been dedicated to understanding what economic and political factors drive poverty and how poverty worldwide might be defeated. Pogge is a member of the Norwegian Academy of Science and Letters as well as co-founder of Academics Stand Against Poverty (www.academicsstand.org), an international network aiming to enhance the impact of scholars, teachers and students on global poverty, and of Incentives for Global Health, a team effort toward developing a complement to the pharmaceutical patent regime that would improve access to advanced medicines for the poor worldwide (www.healthimpactfund.org). In 2012-13, he chaired the Task Force on Illicit Financial Flows, Poverty and Human Rights of the International Bar Association's Human Rights Institute (IBAHRI). In 2013, his article "Are We Violating the Human Rights of the World's Poor?" was awarded the Gregory Kavka Prize in Political Philosophy. ${ }^{2}$ Pogge's recent publications include: Politics as Usual: What Lies behind the Pro-Poor Rhetoric, 2010, and World Poverty and Human Rights, 2nd edition, 2008, both published by Polity Press. In 2008, he also co-edited, with Darrel Moellendorf and Keith Horton respectively, Global Justice and Global Ethics, two volumes of seminal essays published by Paragon House. ${ }^{3}$

Pogge's proposals have strong relevance for political philosophers-who are concerned with examining possibilities for changing the institutional structures that produce global inequalities - and also to policy makers, who can apply his reasoning to real world situations. Pogge has insightfully criticized the current patent system for depriving the poor of access to advanced medicines. To solve this problem, he proposes to create an option for pharmaceutical innovators to be rewarded, from public funds, according to the health impact of their innovation on condition that they sell it at cost. ${ }^{4}$ Another of his innovative proposals is a Global Resources Dividend (GRD) that would charge states for the use of the Earth's natural resources, such as oil, gas and water, and for polluting the natural environment by discharging waste into soil, water and air. GRD revenues would fund development 
in the world's poor regions, ${ }^{5}$ thus enabling the world's poor to obtain a fairer share of the Earth, which in principle belongs to all human beings. In addition to these proposals, Pogge has recently been working on creating a more adequate measure for tracking poverty and gender disparities ${ }^{6}$ and on promoting the curtailment of illicit financial flows facilitated by tax havens, secrecy jurisdictions and shell companies. ${ }^{7}$ His proposals are ambitious in their ideals and deeply philosophical. At the same time, Pogge's proposals are often supported by strong empirical data and statistical analyses, offering evidence for the need to modify actual laws and policies.

In the following interview, Pogge focuses his attention on the situation in Brazil, a country that he says can exert its increasing influence on the design of global institutions. He anticipates the challenges coming for Brazil in combating poverty and gender disparities. He discusses the positive and negative aspects of the Bolsa Família programme, and he suggests that the government should extend its benefits to a larger proportion of the population in order to gain more support from the public. He believes the Bolsa Familia programme is well-designed and that its implementation is essential to mitigating the absurd inequalities that so strongly polarize society and jeopardize democracy in Brazil. To distribute resources to the poor is not a question of charity, as it was considered in the old days, he explains. He finds no justification for affluent Brazilians to control all the country's resources while the poor are deprived of their fair share. Pogge is also concerned that, owing to increasing capital mobility, globalization will tend to benefit Brazil's rich, who also find it much easier to evade taxes. Therefore, in addition to the intervention of social programmes, Pogge recommends that the Brazilian government ensure that the country's wealth is properly taxed and distributed.

\section{Structural Poverty, Social Justice, and the Bolsa Familia programme in Brazil}

Duarte: I will start by citing a provocative sentence from your book: "Even a mere 80 years ago, the poor and unemployed were still often seen as lazy and delinquent merely on the ground that others of equally humble origins had risen from dishwasher to millionaire" (Pogge 2010: 16). When discussing interactional and institutional moral duties, you believe that decades ago, people "did not understand the structural constraints on social mobility" (Pogge 2010: 16), implying that poverty is in part a consequence of a lack of opportunities and possibilities. According to you, people often did not understand that this structural poverty can be influenced by an "intelligent redesign of the rules" and institutions (Pogge 2010: 16). You cite the Bolsa Familia programme in Brazil as an example of an intelligent institutional redesign toward the promotion of social justice in a place where the inequalities were enormous. Indeed, the Bolsa Familia programme seems to have accomplished its goal when, according to the Brazilian government, in February 2013, extreme poverty had officially been eradicated from the country. Ten years after the programme began, one-fourth of the population benefits from it at a cost of a bit more than 0.5 per cent of the country's GDP. ${ }^{8}$ Despite these positive results, a substantial part of the Brazilian middle class aggressively attacks the initiative. They consider the "family allowance" to really be a "laziness grant". According to them, the programme has a pure electoral purpose, promoting no real and long-term benefits for the Brazilian population. Their contention is, however, contradicted by several studies showing positive results produced by the implementation of the programme, ${ }^{9}$ as if they were eighty years late 
in this discussion. My questions are: What could explain such disconnection between the government and the middle-class public opinion? Does the Brazilian middle class truly have anything to fear?

Pogge: This disconnect between the government and middle-class public opinion might be explained by the fact that, in Brazil, the programme does not benefit a majority of the population, but only one-quarter of them. When a social safety net was first instituted in the United States and in Germany, for example, the benefits were enjoyable by a majority of the population. These successful examples show us how to build support for social programmes: benefits must be enjoyable by the majority of the electorate, at least to the extent that they expect to derive significant benefit from the programmes during some period of their life. But such broad diffusion of benefit may be difficult to achieve. Brazilian society is among the most unequal in the world; and in a situation of extreme inequality, it is difficult to construct social programmes so that they benefit the majority of the population. The needs of the extremely poor minority are too urgent to allow dilution of these programmes.

Ideally, we want the programme to cover at least half the population because this could produce a stable electoral majority in its support; but of course we also want the programme to be focused on really benefiting the needy, the poor. Without such a focus, the programme becomes too expensive or too diluted with regard to the very poor. In the case of Brazil, the decision was in favour of a programme that is more focused at the cost of being harder to establish and defend politically. At a cost of half a per cent of GDP, the Bolsa Familia programme benefits one-fourth of the population but excludes a still-struggling segment of the middle class that sees its contribution to the programme as excessive and does not really want to pay for its support of the poor. Such resentment must be considered when designing this type of social programme. It should be discussed with the society: why should we pay for these benefits? How broad do we want the programme to be? It should become clear to the majority of Brazilians that, even though the programme does not benefit them directly, they nonetheless have reason to support it.

As regards the claim that this programme is a benefit for "lazy" people-well, it might be, of course. A programme can be badly designed; but, from what I know, I do not think this is true of the Bolsa Familia programme. It has incentives attached to it, such as immunizations, education, and female participation, which produce actual benefits for the entire country. If, for instance, families immunize their children, then the country will save a considerable amount of money on hospitalizations that would otherwise have to be paid for by SUS, the Brazilian public health system. Furthermore, the immunization of children also averts or curtails the spread of infectious diseases. Incentives to immunize one's children produce social benefits, benefits for all, because anyone's children are potentially at risk of being infected by a child who was not immunized. Such incentives are a public good, benefitting the whole country and all its people. The same can be said of education, which produces a more capable and creative labour force, which in turn enables faster and better economic development. Education also produces a more critical and enlightened electorate, which in turn results in a more sophisticated public policy discourse and better governance and administration. So a well-educated citizenry is also a public good, a form of social capital that enhances the economic opportunities and quality of governance of all. This is especially 
obvious in the case of women who have historically suffered grave educational disadvantages: a society loses greatly if it wastes the creativity and talents of most of its women; and everyone gains when these assets are developed and allowed to thrive. For all these reasons, I am convinced that the characterization of the Bolsa Familia programme as welfare for the lazy is decidedly inappropriate.

In conclusion, let me say that I am commenting on conditions in Brazil with some trepidation because I recognize that, as an outsider, I am not as familiar with the situation as many insiders are. So what I say here should be read with this caution in mind.

\section{The Limits of Distributive Justice}

Duarte: Imagining a situation where everybody has their basic needs fulfilled, but society still maintains large social stratification and a low degree of decommodification, how much would you say we can claim for distributive justice?

Pogge: It is really important for a country to have a spirit of community. Inequality is corrosive. It affects our sense of commitment to the common good, which is what makes us feel we belong together and are all part of the same society. Brazil is a good example of what such corrosive effect of inequality can do to a country. There is a real class division there, which results in hostility between the rich and the poor. Social stratification makes it more difficult for a country to solve its problems because the different groups cannot agree with one another. Therefore, it is on the whole much better to have less inequality rather than more inequality, even when basic needs are ostensibly fulfilled for all. Furthermore, a country has better chances of establishing a successful political system, a democratic political system, when the interests of most people in regard to institutional design and public policies are reasonably well aligned. People will then think in terms of what is best for their country rather than in terms of what is best for their particular social class. The latter thinking can lead to divisive politics, which can deteriorate into a kind of class warfare in which each side is trying to woo the median voter, the middle class, in order to win a majority of the electorate. When political power shifts from one side to the other, the winner will make fundamental changes to the social institutions and policies that are most relevant to the national income and wealth distribution: to the tax system and to social programmes. The winner may even try to change the electoral system so as to make it harder for the other side to regain political power. Such fundamental changes back and forth are costly for the country-just think of the cost of building up some social programme with appropriate administrative staff and then shutting it down again a few years later. And the hostility and nastiness of such politics is another great cost, as we can see currently in the United States, where the people's confidence in the various branches of government has all but disappeared. In order to avoid such problems, in order to maintain a harmonious democracy and an economy that manifests solidarity and allows all citizens to contribute according to their full potential, we need to ensure that social and economic inequalities remain reasonably small. This ensures that the interests of the rich are not too sharply opposed to those of the rest, that not too much is at stake in such conflicts of interest and that the rich are not so rich that they can corrupt the political system and bend it to their will. 


\section{Distributive Justice or Charity?}

Duarte: Currently, the distribution of resources, opportunities, or capabilities is usually concentrated within national borders. International organizations attempting to expand assistance irrespective of national borders, such as UNICEF, the World Food Programme, and Médecins Sans Frontières, are often not financed by taxes, but by charity. This becomes problematic, especially when the continual demands of such institutions provoke what you call "fatigue, aversion, and contempt (...) toward the 'aid' they dispense and its recipients" (Pogge 2010: 55). How would your proposal of a Global Resources Dividend (Pogge 2008: 202-21) change this relationship?

Pogge: At least in the old days, especially under the perspective of the centrality of the nation-state, we thought about measures to protect the poor as charitable measures. We saw gross salaries as reflecting what each person contributes to the social product, and we then saw it as charity when the rich paid higher taxes than the poor, thereby shouldering a larger share of the burden of maintaining the institutions of government. This perception of charity was especially compelling in regard to government programmes that disproportionately benefit the poor. So the state was defending a social and economic order that maintained great inequality and was nonetheless presented and perceived as enforcing charity for the poor at the expense of the rich through "redistributive" taxation. The underlying picture here is that the distribution of income and wealth in a society is the product of two steps: at step 1, people receive a share of the social product that reflects their contribution to it; and at step 2, some of these assets are charitably redistributed by the state so as to make the smaller shares large enough to sustain a minimally decent life.

The fundamental flaw in this picture is the characterization of step 1. Among the essential contributions to the social product are, for example, material assets such as land and natural resources. These assets do not naturally belong to their owners but are assigned to them pursuant to the rules of a specific property system. Such rules typically prescribe that land can be privately owned and accumulated in unlimited quantities, but they might equally well prescribe that land belongs to the community and can be rented for long periods through a competitive bidding process. The choice between such alternative property regimes has a profound impact on the distribution of income and wealth. Thus, while it is true that a person's position in an existing economic hierarchy depends on his or her own efforts (as well as, typically, on those of his or her ancestors), this position, and the entire shape of the distribution, also depend profoundly on the ground rules of the economy. This insight undermines the idea that the step1 distribution is somehow a natural reflection of the contribution or merit of individuals. And it thereby also undermines the idea that step 2 involves charitable re-distribution. Step 2 is better seen as an integral part of the existing property regime, without which this regime might be morally unacceptable as well as unable to maintain itself politically.

Once we understand this point, we are able to rightly conceive that the question is not about redistributive justice, where we have an initial distribution that gets rectified. Rather, the question is simply about distributive justice. In this perspective, we ask: how should an existing social product be distributed? How much should go to landowners? Should landowners be entitled to the full amount they can extract for contributing their land to production or only to some part thereof? Then, when one society taxes land holdings or the income derived from 
land holdings, it has an economic or property system that is different from that of another country with different ownership conditions. Everyone who owns land does so, from the start, on the understanding that the privilege of ownership comes with certain obligations. There is nothing unjust about such obligations as such-just different ways of organizing property rights and land ownership.

The same points apply at the international level, with regard to my proposal of a Global Resources Dividend, for example. With such a GRD in place, the privilege of national domain over some given territory is understood, from the start, as tied to each society's obligation to share with the rest of humankind some of the value of any territorial resources it chooses to exploit. Why should this not be a perfectly sound interpretation of the plausible idea that the Earth belongs to all human beings in common? Think hypothetically about human beings taking stewardship of this planet, knowing very little about where its valuable resources might be located. What system of national property should they institute? There is no natural or selfevident answer to this question - no natural facts we could rely on to determine how the world's land should be divided and what rights exactly each society should have over and within its territory. It is an open question how we should regulate ownership rights and decide who should get what part of the value of natural resources-an open question to be decided in light of considerations of feasibility and efficiency, of course, but also in light of moral concerns and arguments.

In thinking about which rules to adopt, we should-in part, at least-judge any proposed system of rules on the basis of its foreseeable effects. Different systems would have different effects. The GRD system concedes that, for each chunk of natural resources, there ought to be just one agent in control. We do not want everybody to own a share in every bit of the globe; that would be far too complicated and unwieldy. Yet, we also cannot endorse a system, such as we have now, where many people cannot get even a remotely proportional share of the natural resources humanity is extracting from this planet. Nor can we accept that contingencies, such as the scarcity or abundance of water or oil in some particular territory, say, have an excessively large impact on the fate of its inhabitants. The GRD might then be a reasonable compromise: each society has full control of the resources within its territory, but, when it decides to make use of any of these resources, then it must share a small part of the value of these resources with the rest of humankind and specifically with the global poor who would otherwise get much less than a fair share of our planet's resource wealth. This is the basic idea of the GRD. It is just a different way of conceiving property rights from the standard way. We have to be careful, however, to avoid misunderstanding this idea. In the twentieth century, the developing countries fought hard to win full sovereignty over the resources in their territory. This was an important struggle, and I do not want anyone to think that I seek to have its outcome reversed. My proposal is merely that poor and rich countries alike share a small portion of the value of any national resources they choose to use while retaining full control over the decision whether and how to use their national resources. It is also worth emphasizing, in addition, that most of the cost of this GRD would ultimately fall upon the end-users of natural resources, as most of the required dividend payments would be passed along through higher prices. The richer people are the ones with higher consumption, so they would be disproportionately affected by an increase in the price of resource-intensive kinds of consumption (such as air travel). Poorer people would be net beneficiaries, as the 
revenues from the GRD would be spent for their benefit. And all people, including future generations, would benefit from the disincentive (through higher prices) against resource-intensive consumption.

Duarte: Are you suggesting that there should be a difference between land ownership and land management in the case of the nation states?

Pogge: There is certainly a difference. The GRD does not take away any of the management rights from countries. The management rights or the right to control the natural resources available within their territory would definitely stay with the countries, and in this sense the historical victory of the developing countries in their struggle to free themselves from colonialism would remain intact.

To clarify the distinction, imagine, for example, that there is a large amount of oil situated under a holy site of a certain country. If the people in this country decide not to extract the oil in order not to disturb the holy site, their decision should be respected. These people should not even be charged, in my view, for the privilege of blocking access to this resource, because any such charge might put undue pressure on them to reluctantly permit its extraction. If these people decide, however, to extract the resource for their own benefit, then they would on my proposal be required to share some small fraction of the market value of the extracted resource on the principle that the Earth belongs to all human beings in common and that it would be wrong to exclude-as is the current practice-the world's poor from their fair share of our planet's natural wealth.

In the present system, rich people monopolize the natural resources of our planet. Rich people in one country claim ownership over its natural resources and then sell them to other affluent people often residing in other countries. All this happens by mutual consent with nice mutually agreeable contracts under which the resources are processed and finally consumed by affluent people. The world's poor-and this easily includes the entire poorer half of humanity which currently receives only three per cent of global household income-cannot get access to more than a tiny fraction of a proportional share of the natural resources extracted, and this is, in my view, very unfair.

Duarte: It is certainly unfair. With a global resources dividend system the poor would be much less vulnerable to exploitation. Brazil is a country very rich in natural resources, but the resources are still controlled by elites. By distributing these resources to the whole population, Brazil would certainly improve considerably in terms of development, right?

Pogge: Yes, this would surely be a huge boost to development. It would allow poor people to partake in the resource wealth of the country, which should not benefit merely a few rich owners, but all Brazilians. Everyone should partake in natural resource wealth because no one has a prior or superior claim to any of these resources. We have a collective responsibility to regulate the exploitation of natural resources in such a way that no one is excluded from a fair share. This means, in particular, that no one should be allowed to benefit from a much larger than average share without compensating those who are reduced to much smaller than average shares. 


\section{Global Institutions and the Combat of Poverty in Brazil}

Duarte: What is, in your opinion, the role of global institutions in the increase/decrease of poverty in Brazil in the last decade? Do you think that this role will change from now on, since the Brazilian Roberto Azevedo has been selected to be the next director of the World Trade Organization (WTO)?

Pogge: The role of the global institutions with regard to poverty in Brazil will probably not change significantly. This is because decisions by the World Trade Organization are made by consensus, which is driven by the very unequal bargaining power of the member states. With their enormous economic and military might, Western countries will remain the dominant powers in the WTO, even if a Brazilian becomes the body's director. Of course, Brazil is a rising power. It is the seventh-largest economy in the world and, given its size and resources, has a very realistic opportunity to overtake the United Kingdom, France, Germany and Japan in the near future. Brazil's influence is increasing also because it has intelligently aligned itself within the IBSA countries: India and South Africa. They have formed a powerful partnership of rapidly growing countries, which now have substantial influence in and through the G20. This will increasingly help Brazil to develop, to achieve solid rates of economic growth and to protect its interests. It is true that Brazil was badly treated in earlier decades, severely exploited by multinational banks and corporations backed by the United States, which also supported and collaborated with the military dictatorship from 1964 to 1985 . These were unhappy times for Brazil in many ways, politically and economically. Nevertheless, Brazil has now emerged as a country that has largely emancipated itself from this sort of foreign pressure and domination. Brazil cannot be pushed around any more, like it was pushed around twenty, thirty years ago, and this certainly bodes well for progress, prosperity and development.

The great danger now, however, is that both national and supranational institutional arrangements will benefit some Brazilians at the expense of the great majority of their compatriots. Such arrangements might be shaped to aggravate existing social and economic inequalities, which in Brazil are already enormous. This is something we have witnessed all over the world during the last 30 years or so: globalization has led to socio-economic polarization in most countries including, rather dramatically, China and the United States. In recent years, Brazil has managed to escape this trend. Through policies initiated by Lula, ${ }^{10}$ Brazil has actually reduced inequality over the last ten years. But to put this in perspective, I should add that when Lula was elected, inequality in Brazil was among the very highest in the world and it is still very high in comparison to inequality in other countries, especially outside Latin America and Southern Africa. Inequality in Brazil is deeply entrenched and therefore hard to dislodge: it is strongly correlated with race and transmitted from one generation to the next by means of a highly unequal education system. Still, overall I am cautiously optimistic that progress can continue with democratic support from a majority of Brazil's citizens.

Progress on the inequality front will have to be achieved against the influence exerted by global institutional arrangements, which generally favour greater inequality. This is hardly surprising. These global institutional arrangements have rapidly become much denser and more influential during the globalization push of 
the last 30 years. These new global rules (such as those of the WTO), which now reach deep into the inner lives of national societies, were shaped by the governments of the leading developed states, and these governments in turn were heavily influenced by the interests of their most powerful constituents: multinational corporations, large banks, industry associations, hedge funds and billionaires. As a result, globalization is benefitting the rich at the expense of the poor in many different ways. This is not a fact about globalization as such, but a fact about this globalization: globalization under the specific rules and agencies that have emerged or been strengthened over the last 30 years or so.

One could give many examples; here are four: the permitted protectionism the rich countries managed to get "grandfathered" into the WTO Agreement to protect, in particular, their domestic agriculture at the expense of farmers in the poor countries; the very strong intellectual property rules the rich countries imposed upon the rest through the TRIPs Agreement (Trade-Related Aspects of Intellectual Property Rights) (Annex 1C of the WTO Agreement); an international tax system that in effect enables multinational corporations to shift their profits into tax havens and thus to avoid paying taxes in the developing countries where their profits originate; and the facilitation of large, quick and secret movements of capital across national borders, which supports tax evasion, embezzlement, money laundering, human and drug trafficking, terrorism as well as other forms of crime especially in the developing world. These rules affect Brazil and harm, in particular, its poor: sharecroppers, patients and those who depend on the society's social safety net. These same rules also benefit some rich Brazilians who can, for example, keep their wealth in secrecy jurisdictions abroad and thus avoid paying taxes on their earnings from capital. This is actually quite common. The Boston Consulting Group estimates that Latin Americans keep an unimaginable US \$1 trillion abroad; that is 25.6 per cent of their collective financial wealth, while the analogous estimates for North America and Europe are 1.8 per cent and 7.9 per cent, respectively. ${ }^{11}$ Obviously, when poor countries are unable to tax capital income, they must cut back government services or get more of their revenues from taxes on labour income and from consumption taxes, which place greater burdens on the poor.

Now it should also be said that the Brazilian government has taken intelligent steps to improve its tax collection from rich individuals and especially from multinational corporations. Brazil has a comparatively well-run tax system that works better than those in other Latin American countries and much better than those in Africa. Still, Brazil would benefit from international reforms that would increase financial transparency at both the domestic and global levels in order to curb tax avoidance and evasion. Among the most important reforms, governments should mandate: (1) disclosure of the ultimate beneficial owners of companies and of the controlling parties of trusts and foundations; (2) public country-by-country reporting of profits and other tax-relevant information by multinational enterprises; (3) automatic exchange of tax-relevant financial information by national tax authorities worldwide; (4) public reporting on funds paid to governments for the extraction of natural resources and on the use of those funds; and (5) tough sanctions, including jail time, for professionals who facilitate illicit financial flows, for instance senior officers from global banks, accounting firms, law firms, insurance companies and hedge funds. In addition, governments should commit to: (6) harmonizing anti- 
money laundering regulations internationally; and (7) carrying out clear, reliable, frequent and timely public fiscal reporting as well as opening up their fiscal policymaking process to public participation. ${ }^{12}$ Such reforms would promote greater domestic resource mobilization in Brazil and especially also in other, poorer developing countries.

\section{National Partiality and Impartiality in Government Decisions}

Duarte: For a long time, Brazil was a debtor of the International Monetary Fund (IMF). However, the situation has changed and from debtor it became creditor of IMF. Brazil is lending US $\$ 10$ billion to the organization in order to help bail European countries out of their current crisis. ${ }^{13}$ Such government decisions can, perhaps, be seen as "impartial" from a national standpoint since, besides reducing the high rates of poverty within the country, the money is going to be used to help richer countries-which until now have benefited from the Brazilian debt with IMF. In your book (Pogge 2010: 23-4), you said that "partiality of concern is alright within a minimally fair setting, but not all right when it seeks to undermine the minimal fairness of this setting itself." So, my question is: Does impartiality of concern have this minimal fair setting as well? And if it does, do you think that Brazil is overlooking these limits when lending money to the IMF?

Pogge: The system that we have at the moment is certainly not a fair system that takes equally into account the interests of rich and poor people. For this reason, even when not privileging its citizens, the government is not totally impartial. The system we live under is designed by the rich for the rich. Certainly, the system is in the first instance designed by nation states, by governments and by their delegated negotiators who sit together to decide what the rules of the game should be, in the context of the G20, for example. These governments are, however, influenced by their most powerful constituents-by big national industry associations, multinational corporations, banks, hedge funds, billionaires-and unfortunately, the Brazilian government is no exception. Government policies, especially foreign policies and negotiating positions in international negotiations, are very heavily moulded by a country's most powerful constituents, and governments pay far more attention to these powerful constituents than to the poorer majority of the country who often lack the time and education to form opinions on these matters. As a result, the supranational rules of the game, for example those structuring the world economy, are certainly not impartial, certainly not based on the equally weighted interests of all participants.

Now, your question is whether it is all right for Brazil to help overcome the financial crisis in Europe, to give some money to the IMF for the purposes of assisting the Europeans. Now, this is not money given as a donation; it is rather a loan given to the Europeans to shore up their financial system. You might say this is part of a cooperative system, a special sort of insurance scheme where, in case any country falls upon hard times, it can count on the assistance of others, through loans, not through gifts. So it's a bit like a scheme of fire insurance: if someone's house catches fire, then one gets financial assistance for rebuilding, assistance that is funded from the insurance premium of many other homeowners. But there is still this difference, that homeowners get the rebuilding money as a grant whereas countries get IMF funds as a loan that must eventually be paid back. 
In principle, such an insurance scheme is valuable because the overall financial system is an important part of the infrastructure that makes the whole global economic system function. The North Atlantic financial crisis of 2008 was, and still is, a danger to the whole world. Fortunately, the crisis was reasonably contained before producing more damage around the world. It strongly affected the United States and Europe, but it did not really affect Brazil and most other less-developed countries. It affected China because China is a major exporter to the United States and the European Union. Brazil was less affected because the principal destination of its exports is China. In any case, any national economy today depends on the health of the global financial system, and it is therefore in each country's interest to contribute to a fair and effective scheme for stabilizing the world financial system through mutual lending.

Apart from the nice symbolic significance of Brazil's contributing US $\$ 10$ billion (along with other less developed countries) to this bailout of Europe, Brazil benefits from its loan insofar as it will be able to call upon similar support in case of domestic financial difficulties and also insofar as its economic position benefits from a deeper and more severe crisis being averted in Europe and in the United States. To be sure, we must always remember that the present global financial system is not a fair or just system. It is a system skewed in favour of the rich. Still, a deepening of the North Atlantic crisis would have had an adverse impact on Brazil and its citizens. Although some clever rich people in Europe and in North America were able to make a lot of money on the crisis, this was a tiny minority. The vast majority, rich and poor alike, were hurt by the crisis. And because the harm was so widespread, it was genuinely important, I think, to contain this harm, to make sure that the crisis did not become deeper and did not spread into the far more vulnerable poor countries. Given all this, it was the right policy decision to participate in loans to Europe to help bail out the countries most affected by the crises.

\section{Owl of Minerva Spreading its Wings before the Falling of Dusk}

Duarte: According to you, for the first time the owl of Minerva is finally "spreading its wings well before the falling of dusk," and this means that philosophy has actually "been giving an important conceptual impulse to economics, political science, and politics" (Pogge 2010: 25). Will philosophy influence the agenda post-2015 after the first UN Millennium Development Goals (MDGs)? What measures could be taken to limit the possibilities of moving the goal posts and of ensuring that poverty is finally defeated?

Pogge: We are certainly living in a very important time in history. It is a time in which the global institutional architecture is being shaped and in which philosophy can potentially provide important normative input. We also had such a period of globalization and institutional reshaping in the late nineteenth to early twentieth century, but it came to an abrupt and tragic halt with the First World War. It started up a little bit again in the 1920s, but then came the even more horrendous Second World War, of course. Now we are making the third attempt towards a more cosmopolitan order, and this time it looks like such an order will be established and become irreversible. We are building a new global institutional infrastructure, and the rules of this infrastructure are now in the process of being shaped. To build and 
understand this infrastructure, new concepts and theories are necessary: in law, in political science, in economics and also in philosophy.

The emergence of a dense and highly influential global institutional order can be compared to the building of a city, such as New York, for example. New York changes all the time, as people, companies and industries come and go, as buildings get torn down and erected, as transportation and communication systems get modernized. And yet, the basic features of the city stay much the same, even over centuries: the grid of streets, the location of the parks, subway lines, bridges and tunnels, and so on. These basic features have tremendous inertia; they could be altered, but it would be extremely difficult to do so-not only because of the enormous expense involved but also because of the vested interests that have formed around these features. Early decisions about the basic features of the city thus turned out to have a profound influence lasting for centuries. It is similar, I think, with the early decisions that are now being made about the emerging global institutional infrastructure. These basic features, too, will be deeply entrenched by the complexity and expense of altering them as well as by the vested interests that are forming around them. More than most other generations in human history, we are profoundly shaping the future of humanity, not just for the next few decades, but for centuries and (if humanity is so lucky!) millennia to come.

This rapid emergence of a critically important global institutional infrastructure has been going on for 30 years. And it has in many ways been badly designed, morally speaking, in blatant disregard of the needs and interests of the poorer majority of humankind. My generation bears a grave responsibility in this regard. The more progressive people of my generation-those who are concerned about severe poverty and excessive inequality, those who care about human rights and about genuine political participation for all-have, by and large, missed these developments. The global corporate elites, the leaders of business and finance, on the other hand, were highly alert. Overcoming many differences among themselves, they have managed to bring enormous influence to bear on the most powerful politicians and have essentially succeeded in shaping the new global institutional infrastructure according to their shared interests. To be sure, these elites bear no ill will against the poorer majority, not at all. They merely give priority to their own interests. Their great influence thus results in global institutional arrangements that secure them a large and ever-increasing share of global income, which of necessity is associated with rising global inequality and with the persistence of severe poverty as the poorer half of humankind has been reduced to barely 3 per cent of global household income.

Regulatory capture-politicians and regulators coming under the influence of wealthy elites who then dominate the formulation and application of rules-has destructive effects not only on the poor. It also leads to regulatory incoherence and to the neglect of the future. Regulatory incoherence occurs because elite players differ with regard to which rules and regulations will affect them the most. This is where each will concentrate its lobbying efforts. As a result, different parts of the emerging supranational institutional infrastructure are shaped by different interest groups rather than designed for optimal coherence and effectiveness with regard to some chosen purpose. Neglect of the future occurs because elite players are focused on the short term. The CEOs of powerful banks or corporations typically have just a few years until retirement and, during this time, their retention and pay are 
massively dependent on their performance relative to that of their peers at competing enterprises. The long-term health of the world's economy and ecology has no impact on their bonuses and stock options. Hedge fund managers and most large investors are even more clearly focused on the near term. They can quickly switch investments and even "go short" and thereby avoid, or even profit from, any long-term adverse effects of their decisions and lobbying efforts. Regulatory capture magnifies these pathologies insofar as enterprise leaders' myopic appetite for shortterm profits comes to dominate not merely the operations of their respective enterprises but also the policies and institutional-design preferences of their state. Just think about it: the United States is involved in international negotiations whose outcome will shape important aspects of the world economy for centuries, and the US position is formulated by a bunch of powerful enterprise leaders focused on the vast sums they can earn if their respective enterprises make extraordinary profits in the next few years.

Obviously, we need a far more thoughtful and democratic way of building the infrastructure of our increasingly interdependent world. We would be better off if we could think more holistically and universalistically about the kind of cosmopolis we want to build-about the basic features of a political and economic order that could last for centuries. It is in this regard that the owl of Minerva must spread its wings before the falling of dusk: Philosophy can, and should, and is beginning to, play a more constructive role in shaping and revising the emerging global infrastructure with an eye to humanity's long-term future. Given that our institutional design decisions in this crucial phase of human history will profoundly affect the future, we have a responsibility to make these decisions with all the foresight we can reasonably summon. We have to think seriously and with the best academic inputs about how a future fully globalized world should best be governed, how its economic system should work, how its financial system should be designed. How can we envision, a century in the future, a world order that ensures safety, freedom and prosperity for all human beings and is politically reachable from where we are? If we don't face this question systematically, if we just muddle through as directed by the momentary agreements among short-term orientated political and economic elites, then humanity is highly unlikely to attain such a morally liveable world. In fact, we may fail our very first serious test as a species: The challenge of anthropogenic climate change.

About the development goals post-2015, in my lecture at the conference on Realizing Global Justice: Theory and Practice at the UiT The Arctic University of Norway, ${ }^{14}$ I gave a summary of what I think would be goals of the right kind. They differ from the goals that are standardly discussed, such as the MDGs and also their successors, the "Sustainable Development Goals", drafted by a high-level panel of eminent persons. ${ }^{15}$ The goals I advocate differ in that they commit states not merely to the proposition that some outcomes ought to happen, but to concrete changes in the existing institutional arrangements that would actually lead to these outcomes. It is easy to endorse a list of pious wishes: less poverty, more female education, less corruption, better health care. But these good things are not going to happen just because a lot of states agree that they should. What we need is agreement on who is supposed to do what to bring about these good things. For example, to reduce poverty in the less developed countries, we need to stop their being drained of capital and tax revenues by their own economic and political elites and by the 
accounting gimmicks of multinational enterprises. We need to dismantle the financial-secrecy infrastructure of tax havens, shell companies, secrecy jurisdictions and anonymous trusts with their sleazy banks, lawyers and accountants. Concerted action by the affluent states could easily achieve a massive reduction in illicit financial flows. And, driven by post-crisis public anger in these countries, there is actually a great deal of movement now in this direction, in the OECD and the G20, most visibly. This is a great opportunity to achieve the necessary reforms of the international financial system. Here it is crucial that the reforms fully include the needs and interests of the less developed countries, which suffer vastly more from this problem than affluent countries do. So what goals or targets might countries agree upon to really tackle this problem? Well, for example the seven reforms I mentioned earlier.

Duarte: You, Sen, and others have heavily criticized the way poverty has been measured (Pogge 2010, 57-74). Could you quickly update us with your final findings on the development of a holistic way of measuring poverty (Pogge 2010, 75-92)?

Pogge: In May 2013 we had the final conference in Oslo where we presented the results of our research project Measuring Poverty and Gender Disparity. ${ }^{16}$ This was a three-year project of participatory research where we talked with poor people in 18 different sites-one urban, one rural and one marginalized community in each of Angola, Fiji, Indonesia, Malawi, Mozambique, and the Philippines-in order to understand what they think poverty is all about. Our work consisted of three phases. The first phase featured unstructured conversations exploring what constitutes poverty, what the different levels and dimensions of poverty are and how sex and age affect the reality and experience of poverty. From this phase, 25 dimensions of poverty emerged, and we used these as the basis for our more structured interviews in the second phase. On the basis of these interviews, we reduced our measure to 15 important dimensions, distinguishing five levels in each. We also assigned different weights to the dimensions and to the intervals between levels in each dimension; the lowest interval in the most important dimensions received 12 times as much weight as the highest interval in the least important dimensions. Accommodating the reflections of poor people themselves, we ended up with a measure of poverty that is multidimensional, gender-sensitive in its choice of dimensions and also individualistic by assessing the deprivations and hardships of each person (when nearly all other measures of poverty base the poverty status of persons on the condition of the household they belong to). In the third phase, which we had funds to run only in the Philippines, we actually used the poverty measure we had developed for a survey of a random sample of some 1800 people in order to learn how poor people do by the light of our metric and whether this metric offers an appropriate way of measuring poverty and gender disparities. Here we found one very surprising thing: poor women are slightly better off than poor men in the Philippines.

\section{Duarte: Is this because women would better administer their incomes?}

Pogge: This could well be part of the explanation. But in many cases the women and men live together in the same household, and so women's more responsible money management should benefit both. Of course, the surprising result could be a fluke since the difference we found, albeit statistically significant, was small. But the fact 
remains that we did not find what we expected to find: a clear advantage for males. I am sure we would have found such a male advantage in most other countries. Perhaps our result would not hold up statistically if one were to conduct a larger survey or if our survey had not missed a number of absent males. In any case, the result is not a huge embarrassment for our work insofar as much other fieldwork confirms that the Philippines is doing relatively well in terms of gender disparities. According to the 2013 Global Gender Gap Report, ${ }^{17}$ the Philippines is among the top countries in terms of gender equality, number five in the 2013 world ranking. This is not true of Brazil, I am sure.

Duarte: No, unfortunately it is not. Even with a female president, I am afraid to say that Brazil is number sixty-two in the world ranking, way behind the Philippines.

Pogge: I understand, and this is why it is so important to get funding to continue with this project. We hope that in the near future we will get funding to implement our phase-three survey in other countries, such as Fiji, for example.

Duarte: What were the questions you used to build up your data? ${ }^{18}$

Pogge: In different phases we worked with different questions. In the first phase, we started with very open questions, such as: are there different levels of poverty? There are certainly differentiations among the poor, but can one measure these differences? How do we recognize whether a person is poor or extremely poor? We received diverse answers in different countries. In some places, different levels of poverty are recognized by looking at how people sleep: some people sleep on the ground, some people sleep on a kind of mattress. In other countries, differentiations are based on how people are dressed, and so forth. We found more and more of this information and worked it into a schema of levels and dimensions: there are people who are poor, not so poor, and extremely poor. We found that some of the dimensions that poor people stress as important are, superficially at least, quite remote from what in ordinary affluent circles would be considered a marker of poverty. A very important part of the experience of being poor, for example, is vulnerability to violence. Being poor means being exposed to violence. Poor people typically do not have a house or apartment where they can just lock the door behind them and be safe. They may be homeless, perhaps living on the street or in some shelter that others can invade at any time. Very poor people also receive very little protection from the court system or from the police-in fact, violence against the poor is often perpetrated by the police! Poor people are endlessly abused, kicked around, mistreated-with impunity-by their "social betters" by supervisors or employers, by officials and by anyone who feels like it. The prominence poor people give to the experience of violence surprised us, but if this is what poor people say is an important part of poverty, then it is, and we have to pay attention to it, right?

Duarte: What about happiness? Is happiness on your list?

Pogge: No, we did not ask people about their subjective level of satisfaction or happiness.

Duarte: Is this because happiness is very difficult to measure?

Pogge: Yes, partly. But the fundamental problem is that a focus on happiness brings in normatively inappropriate factors including, in particular, a person's ambitions and expectations. Somebody who is raised to expect very little is well adapted to her 
lack of means and may well be content with a meagre, monotonous diet and primitive living conditions. Still, by raising people in this way, we are not overcoming poverty but, if anything, entrenching poverty by ensuring that people are well adapted to it. Think also of the parallel case of gender disparity. A country has not overcome gender disparity when its females are as happy with their subservient role as its males are with their much greater opportunities. This is not merely a conceptual point but a moral one: we ought to achieve a nutritious and diversified diet, hygienic and private sanitation, clean water, and so on, even for people whose extreme poverty has placed such achievements beyond their imagination. And we ought to achieve equal opportunities even for those girls and women whose life-long subordination has thwarted even the development of any such ambition. In this special case, where poor people's ambitions are stunted by their circumstances, it would be inappropriate to use the former to validate the latter. This is not tantamount to asking policymakers to re-educate such people or to force them to accept the amenities of modern life. But, if they are serious about overcoming poverty, then policymakers should provide opportunities for a life free from deprivation, and these opportunities will then help ensure that the next generation, at least, will develop higher ambitions in terms of food, sanitation, shelter, education, health care, and absence of gender-based constraints. To be sure, with such higher ambitions comes loss of the capacity to be content with serious deprivations or with gender-based subservience. Endorsing this trade-off is a moral choice and, I think, the right moral choice-though I realize this is a large subject about which a lot more could be said.

\section{Notes}

${ }^{1}$ Melina Duarte, $\mathrm{PhD}$, is a Researcher in Political Philosophy at UiT The Arctic University of Norway. For more interviews, see: Duarte, M., Jakobsen \& J., Dege, C. (2013: 171-183). She is most thankful to the Justice and Development Research Group, Federal University of Rio Grande do Sul, in Brazil, for valuable discussions on the topics of this interview. Contact: melina.duarte@uit.no.

The interview was held on 23 June, 2013, at UiT The Arctic University of Norway, on the occasion of the international conference on Realizing Global Justice: Theory and Practice. This interview is part of a series of interviews with the keynote speakers. The conference and the interview series were organized by the Pluralism, Democracy, and Justice Research Group funded by the Justice in Conflict Project (2010-2015), Research Council of Norway, in collaboration with the Brazilian magazine Filosofia Ciência \& Vida, edited by Paula Palma Félix.

${ }^{2}$ The paper can be found at http://www.law.yale.edu/documents/pdf/LawJournals/ 1._Pogge.pdf.

${ }^{3}$ Read more about Thomas Pogge at http://pantheon.yale.edu/ tp $4 /$.

4 See links to Pogge's TED talk about this topic and more information at http://www.ted.com/talks/thomas_pogge_medicine_for_the_99_percent.html and www.healthimpactfund.org. See also: Hollis \& Pogge (2008) and Pogge (2008: 222261).

${ }^{5}$ See Pogge (2008: 202-21). See also translation to Portuguese in Pogge (2013a: 99147). 
6 See Pogge (2010: 75-92); Pogge \& Rippin (2013b). See also www.genderpovertymeasure.org/.

${ }^{7}$ Pogge (2013c).

8 See more information at http://www2.planalto.gov.br/especiais/cadernodestaques/marco-2013/gestao-em-destaque/erradicacao-da-extrema-pobreza.

9 See more about the benefits of the program at http://go.worldbank.org/ 3QI1C7B5U0.

${ }^{10}$ Luiz Inácio Lula da Silva was President of Brazil from 2003 to 2011. In 2011, his successor, President Dilma Rousseff, was elected. In 2016, she was impeached.

${ }^{11}$ Boston Consulting Group (2013). Africa and the Middle East are doing even worse than Latin America: fully one third of their collective financial wealth is held abroad, about 1.6 trillion US-dollars.

12 These were among the leading demands that emerged from a crowd-funded Delphi study (http://academicsstand.org/2014/05/asap-study-curbing-illicitfinancial-flows-post-2015) that ASAP completed with a panel of 29 leading experts.

13 Watch the full lecture at http://mediasite.uit.no/Mediasite/Catalog/Full/ 11629ab59d35420d8ab50d3ae1263be621.

${ }^{14}$ For the former, see The Millennium Development Goals Report 2014 (New York City, United Nations 2014), www.un.org/millenniumgoals/2014\%20MDG\% 20report/MDG\%202014\%20English\%20web.pdf. For the latter, see the current draft at http://sustainabledevelopment.un.org/focussdgs.html.

15 For first results on this research, see Pogge \& Rippin 2013. Available at www.post2015hlp.org/wp-content/uploads/2013/05/Pogge-Rippin_Universal-

Agenda-on-the-Multiple-Dimensions-of-Poverty.pdf and at http://www.gender povertymeasure.org/.

16 See 2013 Report at http://www3.weforum.org/docs/WEF_GenderGap_ Report_2013.pdf.

17 Questionnaires and final report are now available at www.genderpovertymeasure.org/publications/.

\section{References}

Duarte, M., Jakobsen \& J., Dege, C. (2013). Reassessing Human Rights: An Interview with Seyla Benhabib. Norsk filosofisk tidskrift 48 (2): 171-183.

Pogge, T. (2008). World Poverty and Human Rights: Cosmopolitan Responsibilities and Reforms, $2^{\text {nd }}$ ed. Cambridge and Malden, Polity Press.

Pogge, T. \& Hollis, A. (2008). The Health Impact Fund: Making New Medicines Accessible for All. Oslo and New Haven, Incentives for Global Health.

Pogge T. \& and Horton, K. (eds). (2008). Global Ethics: Seminal Essays. St. Paul, Paragon House.

Pogge. T. (2010). Politics as Usual: What Lies Behind the Pro-Poor Rhetoric. Cambridge and Malden: Polity Press.

Pogge. T. (2011) “Are We Violating the Human Rights of the World's Poor?” Yale Human Rights \& Development Law Journal 14, no. 2: 1-33. Winner of the 2013 Gregory Kavka Prize in political philosophy administered by the American 
Philosophical

Association.

Available

at www.law.yale.edu/documents/pdf/LawJournals/1._Pogge.pdf

Pogge, T. (2013a) "O Fundo de impacto sobre a saúde e sua justificativa pelo apelo aos Direitos Humanos," translated by Pascoal Teófilo Carvalho Gonçalves, Idéias - Revista do Instituto de Filosofia e Ciências Humanas - Unicamp n. 6: 99-147. Available at www.ifch.unicamp.br/ojs/index.php/ideias/article/view/1395/969.

Pogge, T. (2013b). Tax Abuses, Poverty and Human Rights. Produced by the International Bar Association's Human Rights Institute (IBAHRI) Task Force on Illicit Financial Flows, Poverty and Human Rights, chaired by Thomas Pogge. London: International Bar Association. Available at www.ibanet.org/Article/Detail.aspx?ArticleUid=4A0CF930-A0D1-4784-8D09F588DCDDFEA4.

Pogge, T. \& Rippin N. (2013c). Universal Agenda on the Multiple Dimensions of Poverty. Background research paper submitted to the High Level Panel on the Post-2015 Development Agenda, May. Available at www.post2015hlp.org/wpcontent/uploads/2013/05/Pogge-Rippin_Universal-Agenda-on-the-Multiple-

Dimensions-of-Poverty.pdf.

Pogge, T. \& Sengupta M. (2014). Rethinking the Post-2015 Development Agenda: Eight Ways to End Poverty Now. Global Justice. Theory Practice Rhetoric 7: 3-11.

\section{Consulted Websites}

Pogge's personal web page: http://pantheon.yale.edu/ tp4/index.html.

Information from the Brazilian government about the Bolsa Família programme, March 2013: http://www2.planalto.gov.br/especiais/caderno-destaques/marco2013/gestao-em-destaque/erradicacao-da-extrema-pobreza.

World Bank evaluation of the Bolsa Família programme, 2013: http://go.worldbank.org/3QI1C7B5U0.

Pogge's lecture at the International Conference on Realizing Global Justice: Theory and Practice: http://mediasite.uit.no/Mediasite/Catalog/Full/11629ab59d35420d8ab 50d3ae1263be621.

Measuring Poverty and Gender Disparities: http://www.genderpoverty measure.org

Pogge's TED talk:http://www.ted.com/talks/thomas_pogge_medicine_for_the_99_ percent.html.

Information about the health impact fund at www.healthimpactfund.org.

Global Gender Gap Report 2013 at: http://www3.weforum.org/docs/WEF_Gender Gap_Report_2013.pdf.

Boston Consulting Group, "Global Wealth 2013: Maintaining Momentum in a Complex World," 4 and 11, available at www.bcg.de/documents/file135355.pdf. 